\title{
Penggunaan Metode Praktek Terbimbing Pada Pembelajaran Pendidikan Jasmani untuk Meningkatkan Hasil Belajar Teknik Dasar Lompat Jauh Gaya Jongkok Siswa Kelas VIII-C SMP Negeri 3 Ngimbang Semester II Tahun Pelajaran 2015-2016
}

\author{
KUSNAN \\ E-mail: kusnan@gmail.com
}

\begin{abstract}
Abstrak:
Tujuan penelitian tindakan ini adalah untuk mengetahui apakah penggunaan metode praktek terbimbing pada pembelajaran pendidikan jasmani dapat meningkatkan hasil belajar teknik dasar lompat jauh gaya jongkok siswa kelas VIII C SMPN 3 Ngimbang semester II tahun pelajaran 2015/2016. Sasaran atau subyek penelitian ini adalah semua siswa kelas VIII-C SMPN 3 Ngimbang semester II tahun pelajaran 2015/2016 yang berjumlah 36 siswa. Penelitian ini menggunakan penelitian tindakan (action research) sebanyak dua siklus. Setiap siklus terdiri dari tahap-tahap yaitu rancangan, kegiatan dan pengamatan, serta refleksi. Sebelum memasuki siklus I, terlebih dahulu dilakukan identifikasi pembelajaran pada pra tindakan. Data yang diperoleh berasal dari hasil observasi aktivitas siswa selama mengikuti proses pembelajaran dan juga hasil penilaian terhadap hasil belajar siswa melakukan teknik dasar lompat jauh gaya jongkok. Dari Penelitian yang telah dilakukan melalui 3 siklus, dapat diambil satu kesimpulan bahwa penggunaan metode praktek terbimbing pada pembelajaran pendidikan jasmani dapat meningkatkan hasil belajar teknik dasar lompat jauh gaya jongkok siswa kelas VIII-C SMP Negeri 3 Ngimbang semester II tahun pelajaran 20152016.
\end{abstract}

Kata Kunci: Praktek Terbimbing, Pendidikan Jasmani

\section{Pendahuluan}

\section{Proses Belajar mengajar (PBM) pendidikan jasmani merupakan salah satu aktifitas pendukung bagi seorang pendidik (guru) pendidikan jasmani yang sadar akan tujuan pembelajaran atau intruksional di samping tujuan kurikuler yang dapat dirumuskan dan ditetapkan}

Jurnal Reforma Vol. IV No. 01, Fakultas Keguruan dan IImu Pendidikan, UNISLA 
mengajar yang termuat dengan jelas dan tegas pada Rencana Pelaksanaan Pembelajaran (RPP).

Walaupun demikian, dalam kenyataannya masih banyak proses pembelajaran yang belum dapat mencapai hasil yang optimal dalam keseluruhan tujuan sebagaimana tersebut di atas. Sebagai contoh, pada setiap ujian yang komprehensif masih ada sebagian 
siswa yang mengalami kesulitan dalam menjawab pertanyaan-pertanyaan penguji yang menghendaki jawaban yang aplikatif atau demonstratif, seperti praktek atau memperagakan alat, yang mana hal tersebut juga dialami oleh siswa SMP Negeri 3 Ngimbang, tidak terkecuali pada mata pelajaran pendidikan jasmani, misalnya masih rendahnya kemampuan siswa dalam menguasai materi pembelajaran tentang lompat jauh gaya jongkok, baik dari aspek pemahaman konsep maupun dari aspek demonstratif (praktek). Sebagian besar siswa, khususnya siswa kelas VIII sering mengalami kesulitan dalam melakukan tehnik lompat jauh gaya jongkok. Sebagian besar siswa baru menguasai cara melompat. Mereka belum mampu melakukan teknik dasar gerakan secara benar.

Kondisi tersebut menuntut kepedulian dari para pendidik, dalam hal ini adalah guru pendidikan jasmani untuk melakukan berbagai upaya perombakan, terutama dalam hal penggunaan metode pengajaran yang efektif. Konsep metodologi pengajaran yang baik adalah multhi method yang dalam hal ini, terutama adalah penggunaan metode demonstrasi atau praktek yang berkesinambungan dan menyeluruh sebagai upaya untuk untuk mencapai tujuan pembelajaran, khususnya pada unsur psikomotor. Hal yang terpenting yang perlu diperhatikan dalam hal ini adalah penguasaan metode mengajar termasuk metode demonstrasi (praktek).
Drs. Abu Ahmadi dalam bukunya Metodik Khusus Pendidikan, merumuskan bahwa metode demonstrasi (praktek) adalah metode pengajaran dimana guru atau orang lain atau siswa sendiri diminta memperlihatkan pada seluruh kelas tentang suatu "proses". Pengertian lain menyebutkan bahwa metode demonstrasi (praktek) adalah suatu acara mengajar yang pada umumnya berupa penjelasan verbal dengan suatu kerja fisik atau pengoperasian peralatan.

Dari pendapat mengenai pengertian metode demonstrasi (praktek) sebagaimana tersebut di atas, maka dapat diperoleh ciri dari metode demonstrasi (praktek) yaitu 1) Adanya aktifitas fisik atau peragaan, baik oleh guru maupun siswa, 2) Adanya pesan atau informasi yang dipergunakan, 3) Adanya alat Bantu atau media yang tersedia, 4) Adanya tujuan yang ingin dicapai. Dengan berdasarkan penjelasan tersebut, maka dapat diambil suatu kesimpulan bahwa pengertian dari metode praktek terbimbing adalah suatu metode atau cara yang ditempuh dengan membimbing siswa mulai dari tahap pra praktek (pemahaman konsep pendukung), tahap perencanaan praktek dan tahap pelaksanaan praktek untuk mencapai tujuan pembelajaran praktek.

Berdasarkan latar belakang di atas, maka masalah dalam penelitian ini dapat dirumuskan sebagai berikut: "Apakah penggunaan metode praktek terbimbing pada pembelajaran pendidikan jasmani dapat meningkatkan hasil belajar teknik dasar lompat jauh gaya jongkok siswa 
kelas VIII-C SMP Negeri 3 Ngimbang semester II tahun pelajaran 2015-2016"?

\section{Metode}

Menurut Mukhlis (2000: 5), Penelitian Tindakan Kelas (PTK) adalah suatu bentuk kajian yang bersifat sistematis reflektif oleh pelaku tindakan untuk memperbaiki kondisi pembelajaran yang dilakukan. Adapun tujuan utama dari PTK adalah untuk memperbaiki atau meningkatkan praktek pembelajaran secara berkesinambungan, sedangkan tujuan penyertaannya adalah menumbuhkan budaya meneliti di kalangan guru.

Penelitian ini dilaksanakan sebanyak 1 siklus. Sebelum masuk pada siklus I dilakukan tindakan pendahuluan yang berupa identifikasi permasalahan. Observasi dilakukan pada tiap siklus, dan melakukan kegiatan pembelajaran berdasarkan kompetensi dasar yang ingin dicapai. Proses pembelajaran pada masing-masing siklus dikenai perlakuan yang sama (langkahlangkah kegiatan yang sama), dimana perlakuan dalam setiap putaran (siklus) terdiri dari empat komponen pokok yaitu perencanaan, tindakan, observasi dan refleksi.

Sasaran penelitian ini adalah semua siswa kelas VIII C SMP Negeri 3 Ngimbang semester II tahun pelajaran 2015/2016 yang berjumlah 36 siswa. Instrumen yang digunakan dalam penelitian ini terdiri dari: Rencana Pelaksanaan Pembelajaran (RPP), Lembar Observasi, Lembar Kerja Siswa, lembar penilaian dan alat-alat pendukung lainnya. Metode Data-data yang diperlukan dalam penelitian ini diperoleh melalui observasi pengolahan pembelajaran melalui metode praktek terbimbing, observasi aktivitas siswa dan dari penilaian terhadap hasil belajar siswa melalui pemberian tes uji diri kaitannya dengan tingkat penguasaan teknik dasar lompat jauh gaya jongkok.

Penelitian ini menggunakan teknik analisis data (1) deskriptif kualitatif, yaitu suatu metode penelitian yang bersifat menggambarkan kenyataan atau fakta sesuai dengan data yang diperoleh dengan tujuan untuk mengetahui aktivitas guru dan aktivitas belajar siswa yang mana datanya dapat diperoleh dari hasil observasi dan (2) kuantitatif, yang mana datanya dapat diperoleh dari hasil tes uji diri pada setiap akhir siklus.

Adapun aspek-aspek yang dinilai dalam teknik lompat jauh gaya jongkok dan kriteria pencapaian skor pada setiap aspek teknik dasar lompat jauh gaya jongkok disajikan dalam table-tabel berikut :

\begin{tabular}{|c|c|}
\hline $\begin{array}{c}\text { Aspek } \\
\text { yang } \\
\text { dinilai }\end{array}$ & Indikator Keberhasilan \\
\hline $\begin{array}{l}\text { Teknik } \\
\text { Awalan }\end{array}$ & $\begin{array}{l}\text { 1. Kekuatan langkah dan } \\
\text { kecepatan berlari harus selalu } \\
\text { sama atau rata-rata tetap. } \\
\text { 2. Menjelang } 3 \text { atau } 4 \text { langkah } \\
\text { sebelum balok tumpuan, } \\
\text { melakukan tumpuan dengan } \\
\text { kuat tetapi tidak mengurangi } \\
\text { kecepatan dan panjang langkah }\end{array}$ \\
\hline $\begin{array}{l}\text { Teknik } \\
\text { Tumpuan }\end{array}$ & $\begin{array}{l}\text { 1. Tumpuan kaki dapat dilakukan } \\
\text { dengan kaki yang lebih } \\
\text { dominan. } \\
\text { 2. Pada waktu menumpu, badan } \\
\text { harus condong ke depan } \\
\text { 3. Kaki tumpu menumpu secara } \\
\text { tepat pada balok tumpu }\end{array}$ \\
\hline
\end{tabular}




\begin{tabular}{|c|c|}
\hline $\begin{array}{l}\text { Aspek } \\
\text { yang } \\
\text { dinilai }\end{array}$ & Indikator Keberhasilan \\
\hline & $\begin{array}{l}\text { 4. Kaki diayunkan ke arah depan } \\
\text { atas dengan sudut tolakan kira- } \\
\text { kira antara } 40 \text { sampai } 45 \text { derajat }\end{array}$ \\
\hline $\begin{array}{l}\text { Teknik } \\
\text { Melayang }\end{array}$ & $\begin{array}{l}\text { 1. Meluruskan kaki tumpu } \\
\text { selurus-lurusnya dan secepat- } \\
\text { cepatnya. } \\
\text { 2. Pada waktu naik, badan harus } \\
\text { dapat ditahan dalam keadaan } \\
\text { rileks (tidak kaku) } \\
\text { 3. Melakukan gerakan-gerakan } \\
\text { sikap tubuh di udara (waktu } \\
\text { melayang) }\end{array}$ \\
\hline $\begin{array}{l}\text { Teknik } \\
\text { Mendarat }\end{array}$ & $\begin{array}{l}\text { 1. Menjulurkan kedua tangan } \\
\text { sejauh-jauhnya ke depan } \\
\text { dengan tetap menjaga } \\
\text { keseimbangan badan } \\
\text { 2. Membungkukkan badan dan } \\
\text { lutut hampir merapat ( lutut } \\
\text { dibengkokkan) } \\
\text { 3. Kaki mendarat dilakukan } \\
\text { dengan tumit terlebih dahulu } \\
\text { mengenai tanah }\end{array}$ \\
\hline
\end{tabular}

Tabel 1 : Aspek-aspek penilaian teknik dasar lompat jauh gaya jongkok

\begin{tabular}{|c|l|c|c|}
\hline Aspek & \begin{tabular}{|} 
Indikator \\
Pencapaian
\end{tabular} & $\begin{array}{c}\text { Kriteria } \\
\text { Pencapaian }\end{array}$ & Skor \\
\hline \multirow{2}{*}{$\begin{array}{l}\text { Teknik } \\
\text { Awalan }\end{array}$} & $\begin{array}{l}\text { Kekuatan } \\
\text { langkah, } \\
\text { kecepatan lari } \\
\text { dan } \\
\text { pengambilan } \\
\text { tumpuan awal } \\
\text { sudah benar }\end{array}$ & & \\
& $\begin{array}{l}\text { Kekuatan } \\
\text { langkah dan } \\
\text { kecepatan lari } \\
\text { sudah benar, } \\
\text { tetapi } \\
\text { tumpuan awal } \\
\text { salah }\end{array}$ & Cukup & 3 \\
\hline $\begin{array}{l}\text { Kekuatan } \\
\text { langkah sudah } \\
\text { benar, tetapi } \\
\text { tidak } \\
\text { seimbang } \\
\text { dengan } \\
\text { kecepatan lari, } \\
\text { serta t }\end{array}$ & Kurang & 2 \\
tepat & \\
\hline
\end{tabular}

\begin{tabular}{|c|c|c|c|}
\hline Aspek & $\begin{array}{c}\text { Indikator } \\
\text { Pencapaian }\end{array}$ & $\begin{array}{c}\text { Kriteria } \\
\text { Pencapaian }\end{array}$ & Skor \\
\hline & $\begin{array}{l}\text { tumpuan awal } \\
\text { salah }\end{array}$ & & \\
\hline & $\begin{array}{l}\text { Kekuatan } \\
\text { langkah, } \\
\text { kecepatan lari } \\
\text { dan } \\
\text { pengambilan } \\
\text { tumpuan awal } \\
\text { salah }\end{array}$ & Salah & 1 \\
\hline \multirow{4}{*}{$\begin{array}{l}\text { Teknik } \\
\text { Tumpu } \\
\text { an }\end{array}$} & $\begin{array}{l}\text { Penggunaan } \\
\text { tumpuan kaki, } \\
\text { posisi badan, } \\
\text { ketepatan kaki } \\
\text { tumpu dan } \\
\text { ayunan kaki } \\
\text { sudah benar }\end{array}$ & Benar & 4 \\
\hline & $\begin{array}{l}\text { Penggunaan } \\
\text { tumpuan kaki } \\
\text { dan posisi } \\
\text { badan benar, } \\
\text { tetapi } \\
\text { ketepatan kaki } \\
\text { tumpu dan } \\
\begin{array}{l}\text { ayunan kaki } \\
\text { salah }\end{array}\end{array}$ & Cukup & 3 \\
\hline & $\begin{array}{l}\text { Penggunaan } \\
\text { tumpuan kaki } \\
\text { benar, tetapi } \\
\text { posisi badan, } \\
\text { ketepatan kaki } \\
\begin{array}{l}\text { tumpu dan } \\
\text { ayunan kaki } \\
\text { salah }\end{array}\end{array}$ & $\begin{array}{c}\text { Kurang } \\
\text { tepat }\end{array}$ & 2 \\
\hline & $\begin{array}{l}\text { Penggunaan } \\
\text { tumpuan kaki, } \\
\text { posisi badan, } \\
\text { ketepatan kaki } \\
\text { tumpu dan } \\
\begin{array}{l}\text { ayunan kaki } \\
\text { salah }\end{array}\end{array}$ & Salah & 1 \\
\hline \multirow[t]{2}{*}{$\begin{array}{l}\text { Teknik } \\
\text { Melaya } \\
\text { ng }\end{array}$} & \begin{tabular}{l}
\multicolumn{2}{l}{ Pengaturan } \\
kaki tumpu, \\
sikap badan \\
dan gerakan- \\
gerakan badan \\
di udara \\
sudah benar
\end{tabular} & Benar & 4 \\
\hline & \begin{tabular}{lr}
\multicolumn{2}{l}{ Pengaturan } \\
kaki & tumpu \\
dan & sikap \\
badan & sudah \\
benar, & tetapi \\
gerakan-
\end{tabular} & Cukup & 3 \\
\hline
\end{tabular}




\begin{tabular}{|c|c|c|c|}
\hline Aspek & $\begin{array}{c}\text { Indikator } \\
\text { Pencapaian }\end{array}$ & $\begin{array}{c}\text { Kriteria } \\
\text { Pencapaian }\end{array}$ & Skor \\
\hline & $\begin{array}{l}\text { gerakan badan } \\
\text { di udara salah }\end{array}$ & & \\
\hline & $\begin{array}{l}\text { Pengaturan } \\
\text { kaki tumpu } \\
\text { benar, tetapi } \\
\text { sikap badan } \\
\text { dan gerakan- } \\
\text { gerakan badan } \\
\text { di udara salah }\end{array}$ & $\begin{array}{c}\text { Kurang } \\
\text { tepat }\end{array}$ & 2 \\
\hline & $\begin{array}{l}\text { Pengaturan } \\
\text { kaki tumpu, } \\
\text { sikap badan } \\
\text { dan gerakan- } \\
\text { gerakan badan } \\
\text { di udara salah }\end{array}$ & Salah & 1 \\
\hline & $\begin{array}{l}\text { Posisi kedua } \\
\text { tangan, badan } \\
\text { dan } \\
\text { penggunaan } \\
\text { tumit kaki } \\
\text { sudah benar }\end{array}$ & Benar & 4 \\
\hline \multirow[t]{3}{*}{$\begin{array}{l}\text { Teknik } \\
\text { Mendar } \\
\text { at }\end{array}$} & $\begin{array}{lr}\text { Posisi } & \text { kedua } \\
\text { tangan } & \text { dan } \\
\text { badan } & \text { sudah } \\
\text { benar, } & \text { tetapi } \\
\text { penggunaan } \\
\text { tumit } & \text { kaki } \\
\text { salah } & \end{array}$ & Cukup & 3 \\
\hline & $\begin{array}{ll}\text { Posisi } & \text { kedua } \\
\text { tangan } & \text { sudah } \\
\text { benar, } & \text { tetapi } \\
\text { posisi } & \text { badan } \\
\text { dan } & \\
\text { penggunaan } \\
\text { tumit } \\
\text { salah }\end{array}$ & $\begin{array}{c}\text { Kurang } \\
\text { tepat }\end{array}$ & 2 \\
\hline & $\begin{array}{l}\text { Posisi kedua } \\
\text { tangan, badan } \\
\text { dan } \\
\text { penggunaan } \\
\text { tumit kaki } \\
\text { salah }\end{array}$ & Salah & 1 \\
\hline
\end{tabular}

jauh gaya jongkok tertera pada tabel berikut :

\begin{tabular}{|c|c|c|c|c|c|c|c|}
\hline \multirow[b]{2}{*}{ No } & \multirow[b]{2}{*}{$\begin{array}{l}\text { Nama } \\
\text { Siswa }\end{array}$} & \multicolumn{4}{|c|}{ Skor Aspek Yang Dinilai } & \multirow{2}{*}{$\frac{\check{0}}{\frac{b}{\omega}}$} & $\begin{array}{l}\vec{\pi} \\
\vec{d} \\
\vec{\Xi} \\
\vec{n}\end{array}$ \\
\hline & & 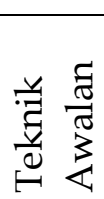 & 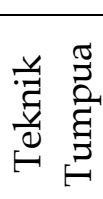 & 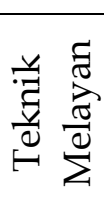 & 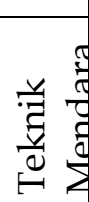 & & \\
\hline & & & & & & & \\
\hline & & & & & & & \\
\hline & & & & & & & \\
\hline & & & & & & & \\
\hline
\end{tabular}

*) Nilai Hasil Belajar siswa diolah dengan rumus

Nilai $=\underline{\text { Jumlah Skor yang diperoleh }} \times$ skala (100) Jumlah Skor Maksimum

berikut :

Penelitian ini dinyatakan berhasil jika memenuhi kriteria: (1) Seluruh perlakuan pelaksanaan metode praktek terbimbing telah dilakukan secara sistematis dan utuh. (2) Ketuntasan belajar klasikal minimal $75 \%$, artinya terdapat $75 \%$ dari jumlah siswa di kelas yang telah tuntas belajar atau mencapai nilai minimal sama dengan KKM yang di berlakukan, yaitu 75 .

\section{Pembahasan}

siswa melakukan teknik dasar lompat

Tabel 2 : Kriteria Pencapaian Skor Setiap Aspek Teknik Dasar Lompat Jauh Gaya Jongkok

Adapun format penilaian hasil belajar siswa terhadap tingkat kemampuan 


Pada fase pra tindakan
(sebelum penerapan metode
praktek terbimbing dilakukan),
perhatian siswa tidak terfokus
pada pembelajaran, terutama pada
saat guru menyampaikan materi,
di samping itu juga sebagian
besar siswa


kurang antusias dalam mengikuti kegiatan pembelajaran.

Pada siklus I, sebagian besar siswa sudah mulai antusias atau sudah mulai fokus mengikuti proses pembelajaran. Siswa sudah mau berlatih dengan sungguh-sungguh. Hal tersebut menunjukkan penggunaan metode praktek terbimbing dalam proses pembelajaran bisa diterima oleh sebagian besar siswa. Kondisi tersebut menunjukkan adanya perubahan yang lebih baik terhadap kondisi belajar siswa jika dibandingkan dengan kondisi belajar siswa pada pra tindakan.

Pada siklus II, sebagian besar siswa sangat antusias dan terlihat semakin serius dalam mengikuti proses pembelajaran, hampir tidak ditemukan siswa yang bercanda dengan temannya selama proses pembelajaran berlangsung, bahkan sebagian besar siswa sudah mau berkonsultasi kepada guru atau kolaborator. Hal tersebut menunjukkan bahwa kondisi belajar siswa mengalami peningkatan kearah yang lebih baik, atau dapat dikatakan bahwa kualitas proses pembelajaran pada siklus II lebih baik jika dibandingkan dengan proses pembelajaran pada siklus I

\section{Hasil Belajar Siswa}

Pada fase pra tindakan, diketahui bahwa hasil penilaian terhadap kemampuan lompat jauh gaya jongkok menunjukkan, hanya 14 siswa dari 36 siswa (30\%) yang telah memperoleh nilai di atas KKM atau telah tuntas belajar. Hasil tersebut menunjukkan bahwa tingkat keberhasilan pembelajaran pada pra tindakan masih sangat rendah.

Pada siklus I dapat diketahui bahwa hasil penilaian kemampuan siswa dalam melakukan teknik dasar lompat jauh gaya jongkok mengalami peningkatan jika dibanding pencapaian hasil belajar siswa pada pra tindakan, yaitu sebanyak 27 dari 36 siswa (75\%) telah mencapai KKM atau telah tuntas belajar (pada pra tindakan hanya 14 siswa atau 30\%). Peningkatan hasil belajar tersebut tidak terlepas dari upaya guru memperbaiki proses pembelajaran berdasarkan kondisi pembelajaran sebelum penelitian dilakukan.

Pada siklus II dapat diketahui bahwa hasil belajar siswa dalam melakukan teknik dasar lompat jauh gaya jongkok pada siklus II mengalami peningkatan jika dibanding pencapaian hasil belajar siswa pada siklus I, yaitu sebanyak 31 dari 36 siswa (86\%) telah mencapai KKM atau telah tuntas belajar (pada siklus I terdapat 27 siswa atau 75\%). Peningkatan hasil belajar siswa pada siklus II tersebut tidak terlepas dari upaya guru memperbaiki proses pembelajaran berdasarkan hasil refleksi pembelajaran pada siklus I.

Untuk mengetahui secara jelas perubahan kondisi belajar siswa dan data-data hasil belajar siswa sebagaimana tersebut di atas disajikan dalam bentuk grafik berikut : 


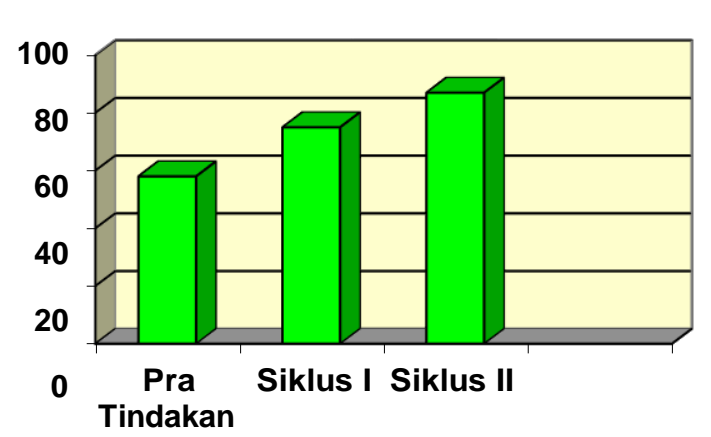

Grafik 1 : Tingkat Aktivitas Belajar Siswa

Pada Pra Tindakan, Tindakan Siklus I dan

Siklus II

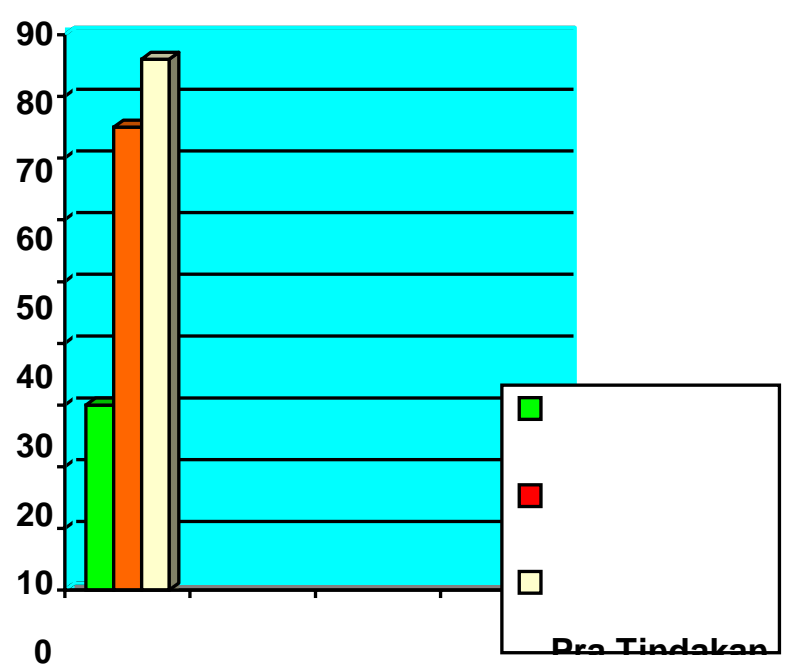

Grafik 2 : Tingkat Pencapain Hasil Belajar Siswa Pada Pra Tindakan, Tindakan Siklus I dan Siklus II

Dari data-data yang telah diperoleh selama pelaksanaan tindakan siklus I dan siklus II pada proses pembelajaran melalui metode praktek terbimbing sebagaimana tersebut di atas, maka dapat diuraikan hal-hal sebagai berikut:

1) Berdasarkan data hasil pengamatan diketahui bahwa dalam mengikuti kegiatan pembelajaran metode praktek terbimbing, secara bertahap siswa mampu meningkatkan aktifitas teknik dasar lompat jauh gaya jongkok.

2) Adanya upaya perbaikan terhadap segala kekurangan pada siklus sebelumnya, sehingga pencapaian pada siklus berikutnya mengalami peningkatan.

3) Pencapaian hasil pada siklus II

dan kualitas belajarnya, sehingga berdampak positif terhadap peningkatan kemampuan melakukan 
menunjukkan bahwa penggunaan

metode praktek terbimbing pada

proses pembelajaran pendidikan

jasmani dapat menciptakan

keantusiasan dan keseriusan siswa

dalam proses belajarnya sehingga berdampak positif bagi peningkatan kemampuan dalam menerapkan teknik-teknik dasar lompat jauh gaya jongkok

\section{Kesimpulan}

Dari hasil serangkaian analisis data dan pembahasannya, maka dapat diambil satu kesimpulan bahwa penggunaan metode praktek terbimbing pada pembelajaran pendidikan jasmani dapat meningkatkan hasil belajar teknik dasar lompat jauh gaya jongkok siswa kelas VIII C SMPN 3 Ngimbang semester II tahun pelajaran 2015/2016.

\section{Daftar Pustaka}

Agus Kristiyanto.2010. Penelitian Tindakan Kelas (PTK) Dalam Pendidikan Jasmani \& Kepelatihan Olahraga. Surakarta: UNS Press 
Arma Abdoellah. 1981. Olahraga Untuk Perguruan Tinggi. Yogyakarta : Sastra Hudaya

Dadang Heryana, Giri Verianti. (2010). Pendidikan Jasmani Olahraga dan Kesehatan Untuk Siswa SMP. Jakarta: Aneka IImu

Depdiknas. (2003). Kurikulum 2004 Standar Kompetensi Mata Pelajaran Pendidikan Jasmani Tingkat SMP. Jakarta: Depdiknas

Depdiknas. (2007). Naskah Akademik Pendidikan Jasmani Olahraga dan Kesehatan. Jakarta: BPP Pusat Kurikulum

Djumindar, Mochamad. (2004). Gerakangerakan Dasar Atletik dalam Bermain. Jakarta: Grafindo Persada

Departemen Pendidikan dan Kebudayaan, 1994. Petunjuk Pelaksanaan Proses Belajar Mengajar, Jakarta. Balai Pustaka.

Puspitasari. 2003. Strategi-strategi Belajar. Jakarta : Direktorat Pendidikan Lanjutan Pertama Ditjen Dikdasmen Depdiknas.

Arikunto, Suharsimi. 1998. Prosedur Penelitian Suatu Pendekatan Praktek. Jakarta: Rineksa Cipta 